\title{
Mineral Chemistry of REE-Rich Apatite and Sulfur-Rich Monazite from the Mushgai Khudag, Alkaline Volcanic-Plutonic Complex, South Mongolia
}

\author{
Dorjpalma Enkhbayar1* ${ }^{*}$, Jieun Seo1, Seon-Gyu Choi' ${ }^{1}$, Young Jae Lee1, \\ Enkhbayar Batmunkh ${ }^{2}$ \\ ${ }^{1}$ Department of Earth and Environmental Sciences, Korea University, Seoul, Korea \\ ${ }^{2}$ Geological Investigation Center of Mongolia, Ulaanbaatar, Mongolia \\ Email: "Dorjpalma.E@gmail.com
}

Received 7 December 2015; accepted 19 January 2016; published 22 January 2016

Copyright (C) 2016 by authors and Scientific Research Publishing Inc.

This work is licensed under the Creative Commons Attribution International License (CC BY).

http://creativecommons.org/licenses/by/4.0/

(c) (i) Open Access

\begin{abstract}
The Mushgai khudag volcanic-plutonic complex consists of four REE mineralization zones: carbonatite zone, apatite zone, magnetite zone, and monazite zone. REE mineralization occurs within peripheries of alkaline magmatic rocks which consist of porphyritic syenite, microsyenite and quartz syenites. Three types of LREE-rich apatite can be found in the carbonatite, apatite, and monazite zones. Crystal-1 type of apatite exists as hexagonal prismatic shape and is mostly found in the apatite zone, and in syenite. Crystal- 2 type of apatite can be exposed also at the apatite zone, and carbonatite zone as brecciated massive crystalline aggregate. Crystal-3 type of apatite demonstrates the compositional zoning texture with monazite as inter-zoning, and is only found in monazite zone. The LREE-bearing apatites from the Mushgai khudag complex are mostly fluorapatite to hydroxyl-bearing fluorapatite with variable REE content. Apatites from the monazite zone present individual sulfur-rich monazite grain, and are formed by comprehensive substitutions.
\end{abstract}

\section{Keywords}

Fluorapatite, Hydroxyl-Bearing Fluorapatite, Sulfur-Rich Monazite, Mushgai Khudag

\section{Introduction}

The Mushgai khudag alkaline volcanic-plutonic complex with REE-Sr-Fe-F-P mineralization is located in "Corresponding author.

How to cite this paper: Enkhbayar, D., Seo, J., Choi, S.-G., Lee, Y.J. and Batmunkh, E. (2016) Mineral Chemistry of REE-Rich Apatite and Sulfur-Rich Monazite from the Mushgai Khudag, Alkaline Volcanic-Plutonic Complex, South Mongolia. International Journal of Geosciences, 7, 20-31. http://dx.doi.org/10.4236/ijg.2016.71003 
South-Gobi, Mongolia. Russian and Mongolian Joint Geological Expedition discovered the Mushgai khudag complex in early 1970's. Since that, number of new studies about alkaline rocks, carbonatites, and REE mineralization the deposit has been completed [1]-[4].

Geological and geochemical surveys demonstrated a wide occurrence of ore-bearing rocks containing rare earth elements with economic grades, especially light lanthanides and also strontium and barium [5]. The alkaline complex is composed of various types of LREE enriched rocks significantly apatite rocks and monazite-rich apatite rock. LREE-rich apatites contain up to $14 \% \mathrm{LREE}_{2} \mathrm{O}_{3}$, while monazite up to $68 \% \mathrm{LREE}_{2} \mathrm{O}_{3}\left(\mathrm{LREE}_{2} \mathrm{O}_{3}\right.$ represent sum of $\mathrm{La}_{2} \mathrm{O}_{3}, \mathrm{Ce}_{2} \mathrm{O}_{3}, \mathrm{Nd}_{2} \mathrm{O}_{3}$, and $\mathrm{Pr}_{2} \mathrm{O}_{3}$ ).

In this study, we discuss the chemistry of LREE-rich apatite crystals from the Mushgai khudag complex. Apatite from the Monazite zone, which has unusual crystal texture with high LREE composition, is main contribution of the study because such type of apatite with individual monazite is rarely found in naturally. Three types of apatite crystals have been examined. Crystal-1 is euhedral and sometimes associated with celestine grains, and crystal-2 is subhedral and brecciated, whereas crystal-3 has an unusual idiomorphic crystal that demonstrates compositional zoning texture and associated with sulfur-rich monazite grains.

Monazite associated with apatite was studied in natural occurrences [6]. Moreover, experimental studies conducted that monazite forms from the host apatite via the action of fluids [4] [7]. In the apatite structure, ( $\mathrm{Y}+$ REE) are principally charge balanced through the coupled substitutions: 1$\left.) \mathrm{Si}^{4+}+(\mathrm{Y}+\mathrm{REE})^{3+}=\mathrm{P}^{5+}+\mathrm{Ca}^{2+}, 2\right)$ $\mathrm{Na}^{+}+(\mathrm{Y}+\mathrm{REE})^{3+}=2 \mathrm{Ca}^{2+}[8]$. Apatite from the monazite zone exhibits the compositional zoning texture. The individual monazite band formed in apatite. Interestingly, we note that monazite found in this study is enriched in $\mathrm{S}(0.93-14.72), \mathrm{Sr}$ and $\mathrm{Ca}(\leq 7.21$ and $\leq 8.25 \mathrm{wt} . \%$ oxides, respectively). Incorporation of these elements in the monazite structure involves the complex substitution: $\mathrm{Ce}^{3+}+\mathrm{P}^{5+}=\mathrm{Ca}^{2+}\left(\mathrm{Sr}^{2+}\right)+\mathrm{S}^{6+}$ to form of sulfur-rich monazite [9].

\section{Geological Background}

The Mushgai khudag alkaline complex is associated with late Jurassic alkaline magmatic activity close to the Main Mongolian lineament along where Mesozoic rift structures have been developed. The Mushgai khudag alkaline complex is hosted in the Silurian-Devoniun Mandal-oboo Formation's turbidite sediments, lower Devoniun Orgol Formation's carbonate sediments, and mid Devoniun Bot-uuli Formation's volcanic sediments [10] (Figure 1).
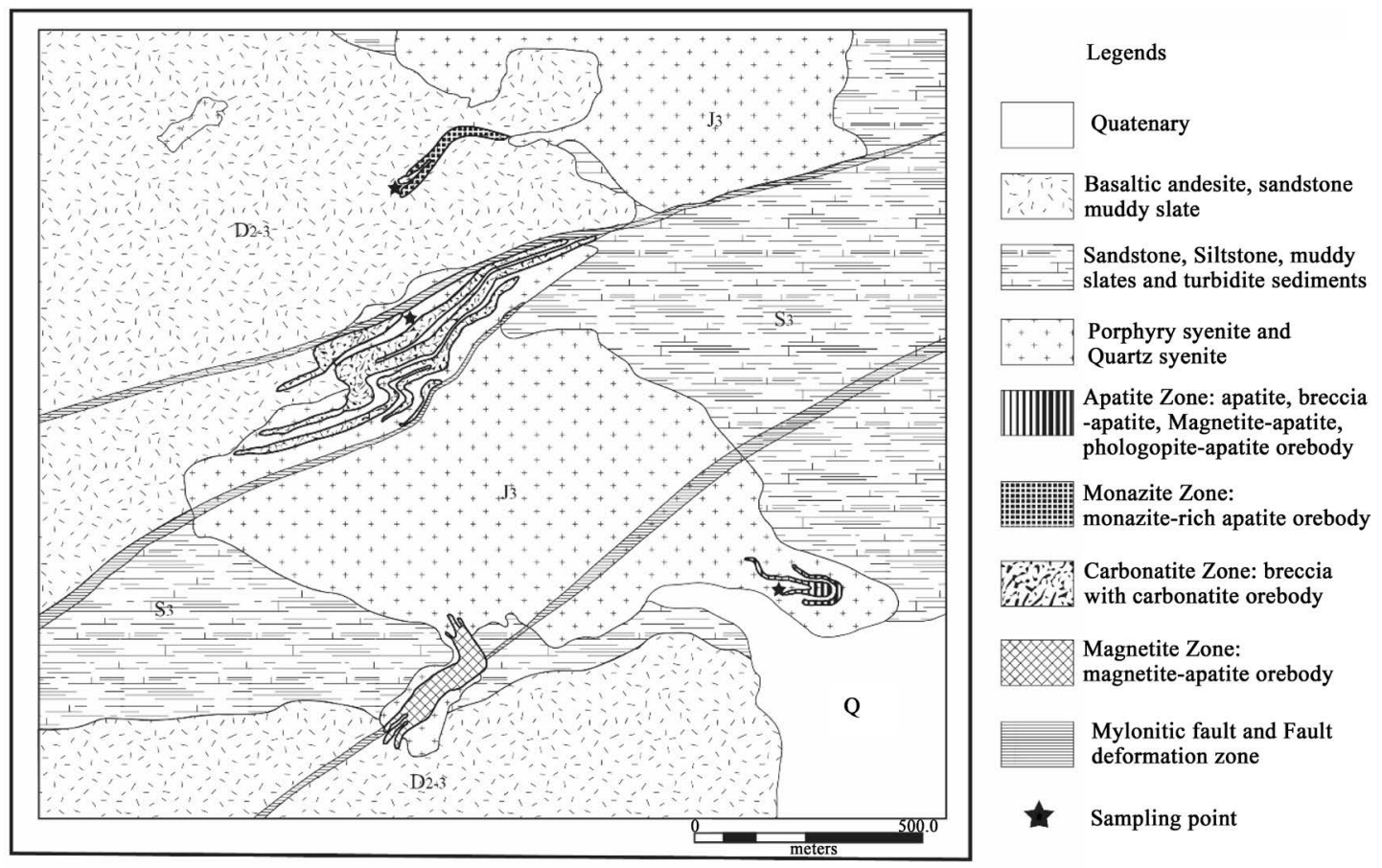

Figure 1. Geological map of the Mushgai khudag deposit (modified from exploration report, “Mongol gazar” LLC, 2010). 
Late Jurassic alkaline complex consists of trachytic volcanics and alkaline syenites, melanephelinite, and melaleucitite. K-Ar ages of alkaline rocks vary from 161 to $121 \mathrm{Ma}$ [5] and Rb-Sr isochron ages is $139 \mathrm{Ma}$, respectively [2].

REE mineralization zones occur peripheries of the late Jurassic alkaline intrusives. The peripheries of intrusives and their roofs are characterized by distribution of quartz-syenite, micro-syenites and porphyritic syenite dykes. Large rectangular-shaped porphyritic phenocrysts in porphyritic syenite and quartzsyenite demonstrate a rapakivi texture where phenocrysts of K-feldspar $\left(\mathrm{Ab}_{5-27} \mathrm{An}_{0-3} \mathrm{Or}_{70-94}\right)$ are rimmed by plagioclase $\left(\mathrm{Ab}_{68-97} \mathrm{An}_{2-20}\right.$ $\mathrm{Or}_{0-11}$ ). Coarse-grained K-feldspar phenocrysts compose main groundmass of quartzsyenite and porphyritic syenite. Round-shaped porphyritic phenocrysts of micro-syenite show an antirapakivi texture with phenocrysts of plagioclase $\left(\mathrm{Ab}_{65-73} \mathrm{An}_{18-25} \mathrm{Or}_{5-10}\right)$ rimmed by K-feldspar $\left(\mathrm{Ab}_{3-14} \mathrm{Or}_{86-94}\right)$. Fine-grained mostly K-feldspar $\left(\mathrm{Ab}_{7-8}\right.$ Or $\left._{79-93}\right)$ phenocrysts composed groundmass of micro-syenite. The quartz-syenite consist of $(<5$ vol.\%) quartz grains that shows poiklitic texture [1].

The carbonatite zone in central part of alkaline complex has approximately $1 \mathrm{~km}$ length and 500 meter width. The largest mineralized zone is composed of low-grade REE carbonatite rocks (total LREE 1.64 - 2.11 wt.\%). The Magnetite zone is composed of massive magnetite rocks, and low-grade LREE-bearing apatite veins occur in massive magnetite rocks's cracks (LREE up to 0.11 wt.\%). The Apatite zone is composed of various type apatite rocks with high-grade LREE (5 - 10 wt.\%). Monazite zone composed of high-grade apatite rocks that contain LREE up to $10 \mathrm{wt}$ \%. The apatite rocks from monazite zone demonstrate zoning apatite with individual sulfur-rich monazite grain (Figure 1).

\section{Mineral Chemistry}

\subsection{Analytical Method}

Mineral compositions were determined using an electron microprobe (JEOL JXA-8600 SX) with energy dispersive spectroscopy (INCA-6025, Oxford Instruments) at Korea University, Seoul, South Korea. The microprobe was operated with an accelerating voltage $=15.0 \mathrm{kV}$, beam current $=3.0 \mathrm{nA}$, live time $=100$ seconds, and probe diameter $=3 \mu \mathrm{m}$. Used standards materials: e.g. quartz $\left(\mathrm{SiO}_{2}\right)$ for $\mathrm{Si}$, corundum $\left(\mathrm{Al}_{2} \mathrm{O}_{3}\right)$ for $\mathrm{Al}$, magnetite $\left(\mathrm{Fe}_{3} \mathrm{O}_{4}\right)$ for $\mathrm{Fe}$, rutile $\left(\mathrm{TiO}_{2}\right)$ for $\mathrm{Ti}$, manganosite $(\mathrm{MnO})$ for $\mathrm{Mn}$, wollastonite $\left(\mathrm{CaSiO}_{3}\right)$ for $\mathrm{Ca}$, jadeite $\left(\mathrm{NaAlSi}_{2} \mathrm{O}_{6}\right)$ for $\mathrm{Na}$, for sanidine $\left(\mathrm{KAlSi}_{3} \mathrm{O}_{8}\right)$ for $\mathrm{K}$, Ni-oxide $(\mathrm{NiO})$ for $\mathrm{Ni}$, fluorite $\left(\mathrm{CaF}_{2}\right)$ for $\mathrm{F}$, apatite $\left(\mathrm{Ca}_{5}\left(\mathrm{PO}_{4}\right)_{8}(\mathrm{OH})\right)$ for P, REEs $\left(\mathrm{LaB}_{6}\right.$, $\mathrm{NdB}_{6}, \mathrm{CaB}_{6}$ ) for LREE with SPI and JEOL Company.

\subsection{Apatite}

Three types of apatite crystals have been analyzed. In BSE image, euhedral elongated large apatite crystal-1 contains numerous of celestine inclusions (Figure 3(a)). Apatite crystal-1 from Apatite zone contains LREE (up to 3 wt.\% $\mathrm{Ce}_{2} \mathrm{O}_{3}$ ). Such type of apatite crystals are mostly euhedral and contained LREE (0.72 - 5.52 wt.\%), (Table 1).

Subhedral, brecciated apatite crystals are included in apatite crystal-2 type. In BSE image, apatite crystal-2 shows round shape and discerns to dark and light areas (Figure 3(b)). Dark areas of the apatite crystal-2 contain $\mathrm{LREE}_{2} \mathrm{O}_{3}$ (11.44 wt.\%), whereas light areas are contained $\mathrm{LREE}_{2} \mathrm{O}_{3}$ (13.27 wt.\%), (Table 1).

Apatite crystal-3 demonstrates euhedral compositional zoning textures. In BSE image, the most compositional zoning apatite ranges from LREE depleted in core1 (moderate), core2 (dark) areas (up to 10 wt.\% $\mathrm{Ce}_{2} \mathrm{O}_{3}+$ $\mathrm{La}_{2} \mathrm{O}_{3}+\mathrm{Nd}_{2} \mathrm{O}_{3}$ ), and LREE strong enriched in rim1 (light) area (up to 14.64 wt.\% $\mathrm{Ce}_{2} \mathrm{O}_{3}+\mathrm{La}_{2} \mathrm{O}_{3}+\mathrm{Nd}_{2} \mathrm{O}_{3}$ ) (Figure 3(c), Figure 3(d)). Representative apatite compositions from the REE ores and host rocks are given in Table 1. The compositional variations of apatite are plotted in the solid solution among F-OH-Cl diagram [12] (Figure 2). The REE-bearing apatites from the Mushgai khudag deposit are mostly fluorapatite to hydroxyl-bearing fluorapatite with variable REE contents.

\subsection{Monazite}

The monazite at Carbonatite and Monazite zone occur as fine particles. Sometimes very fine-grained monazite particles mostly associated with celestine at Carbonatite zone (Figure 3(e), Figure 3(f)).

The fine-grained subhedral monazite grains, associated with apatite, mostly occur as a rim of apatite crystals at Monazite zone (Figure 3(c), Figure 3(d)). Representative monazite compositions from the REE ores are given 


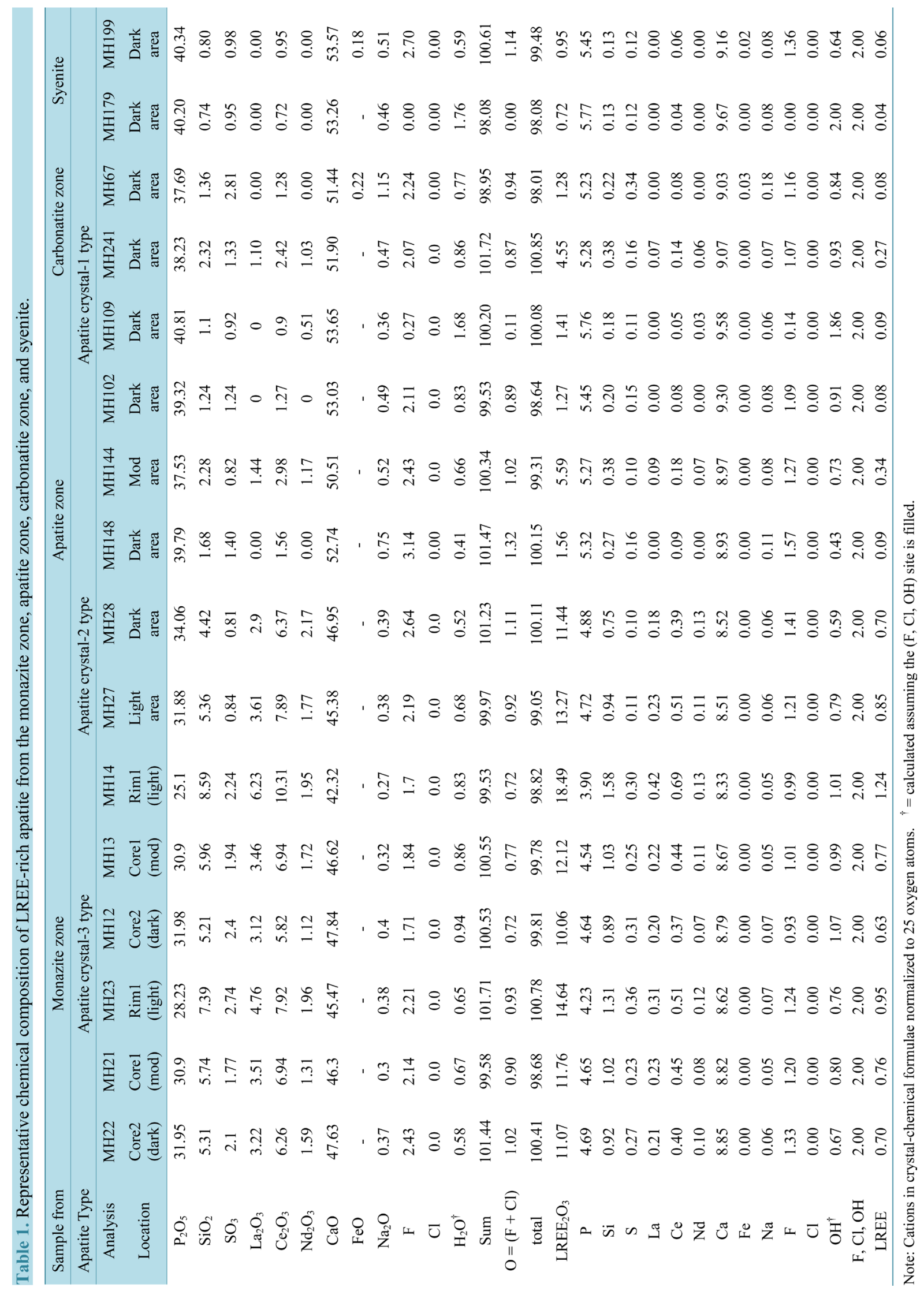




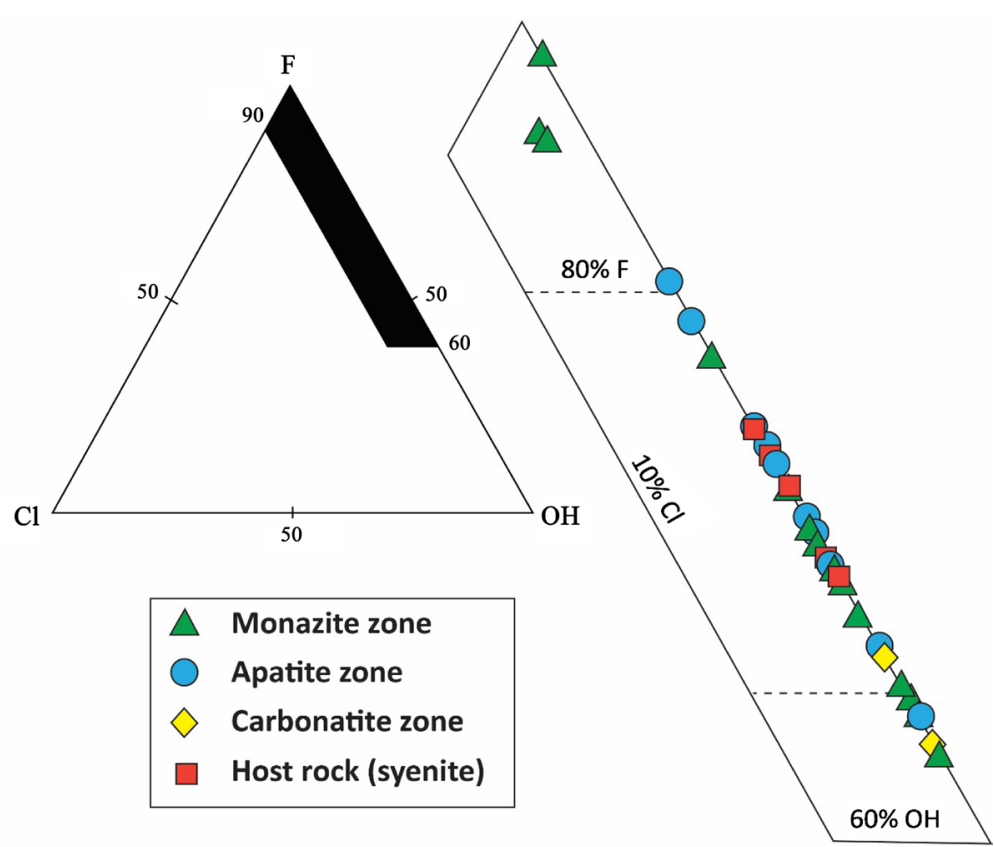

Figure 2. Apatite is showing solid solution among F-OH-Cl end-members, (after Pan and Fleet, 1995). The apatite represents fluorapatite and hydroxyl-bearing fluorapatite.

in Table 2. The monazite associated with fluorapatite or hydroxyl-bearing fluorapatite. The apatites show idiomorphic crystal grains, and compositional zoning texture. They have commonly LREE-poor core2 (dark area), LREE-rich core1 (moderate), rim1 (light areas). The apatites in the syenites, apatite zone and carbonatite zone have a high content of phosphate and calcium with depletion in Si, Na, and LREE, whereas apatite from monazite zone has a low content of $\mathrm{P}$ and $\mathrm{Ca}$ with increasing of Si, $\mathrm{Na}$, and LREE (Figure 4).

The substitution of $\mathrm{Si}$ and/or Na from the apatite structure without coupled removal of $(\mathrm{Y}+\mathrm{REE})^{3+}$ the resulting charge imbalance, due to the coupled substitution reactions in apatite from Monazite zone namely:

$$
\begin{gathered}
\mathrm{Si}^{4+}+(\mathrm{Y}+\mathrm{REE})^{3+}=\mathrm{P}^{5+}+\mathrm{Ca}^{2+} \\
\mathrm{Na}^{+}+(\mathrm{Y}+\mathrm{REE})^{3+}=2 \mathrm{Ca}^{2+}
\end{gathered}
$$

As pointed by Harlov (2013) and Pan (1997), the substitutions encouraged the removal of $\mathrm{Ca}^{2+}$ and the subsequent growth of monazite and/or xenotime inclusions within the apatite grain body via dissolution-precipitation from the $\mathrm{P}^{5+}$ available in the immediate vicinity of the growing crystal and $(\mathrm{Y}+\mathrm{REE})^{3+}$ transported in from over a much broader area [4] [6] [13].

The intensive coupled substitutions with $(\mathrm{Y}+\mathrm{REE})^{3+}$ contributed the nucleation of the individual sulfur-rich monazite between the rim1 and the rim 2 area in the apatite from Monazite zone (Figure 3(d)).

Principally, in the monazite structure, rare earth elements are charge balanced by substitution scheme: $2 \mathrm{Ce}^{3+}=$ $\mathrm{Ca}^{2+}\left(\mathrm{Sr}^{2+}\right)+\mathrm{Th}^{4}$ that known as Th-bearing barbantite and Th, Ca, Sr-bearing strontiobrabantite [11] [14] [15].

This substitution scheme is not applicable for monazite from the Mushgai khudag, Mongolia, because relative depletion of Th content. Th was not detected due to below detection limit. Nevertheless, samples from the monazite-bearing apatite at the Monazite zone demonstrate Th content around (300 - 400) ppm in XRF data [1]. Therefore another mechanism of substitution as inferred by Chakhmouradain (1999) may account for the monazite from the Mushgai khudag complex, that $\mathrm{Ce}^{3+}+\mathrm{P}^{5+}=\mathrm{Ca}^{2+}\left(\mathrm{Sr}^{2+}\right)+\mathrm{S}^{6+}$ [9] [16].

The monazite in the Mushgai khudag complex contains high S in nature (1.5 - 14.72 wt.\% $\mathrm{SO}_{3}$ ), and enriched in $\mathrm{Sr}$ and $\mathrm{Ca}$ (up to 7.21 and $\leq 8.25$ wt.\% oxides, respectively). Our data show $\mathrm{S}$ and $\mathrm{P}$, S, and LREE moderate negative trend (Figure 5(a), Figure 5(c)), whereas $\mathrm{S}$ and $\mathrm{Ca}^{2+}, \mathrm{Sr}^{2+}$ divalent cations represent weak positive pattern (Figure 5(b)), implying that $\mathrm{Ce}^{3+}+\mathrm{P}^{5+}=\mathrm{Ca}^{2+}\left(\mathrm{Sr}^{2+}\right)+\mathrm{S}^{6+}$ scheme of substitution should be a major mechanism of incorporation of $\mathrm{Ca}, \mathrm{Sr}$ and $\mathrm{S}$ in the composition of monazite from the Mushgai khudag complex, South Mongolia. 

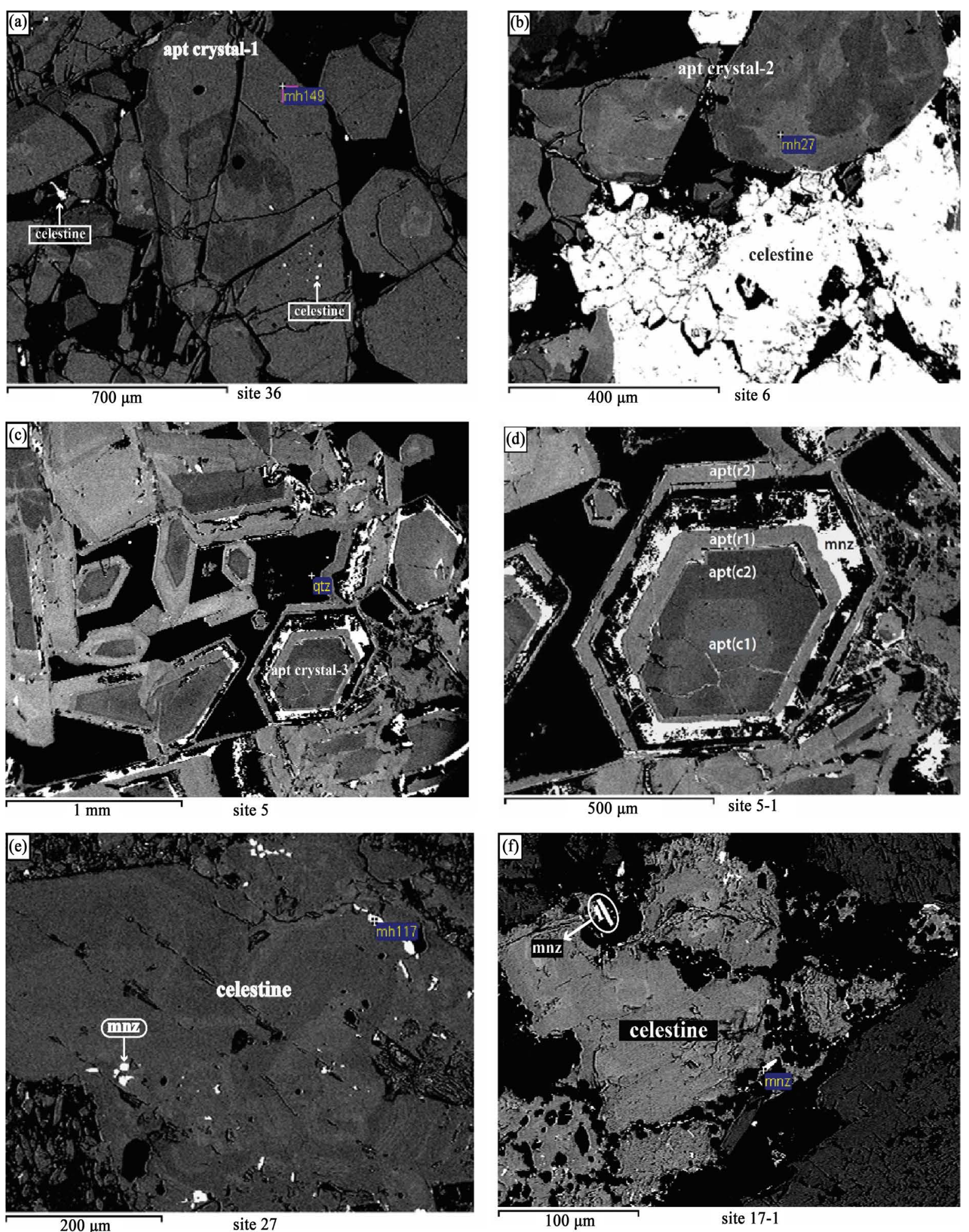

Figure 3. (a) Euhedral apatite crystal-1 from apatite zone and celestine inclusions associated with apatite crystal; (b) Subhedral apatite crystal-2 from apatite zone and celestine. Apatite crystal-2 can be discern to dark and light areas; (c) Euhedral apatite crystal-3 associated with monazite grains; (d) Apatite crystal-3 can be discern to core1 (c1) moderate, core2 (c2) dark, and $\operatorname{rim} 1\left(r_{1}\right)$, rim2 $\left(r_{2}\right)$ light areas. Monazite grain occurs between $\operatorname{rim} 1\left(r_{1}\right)$ and $\operatorname{rim} 2\left(r_{2}\right)$; (e) Subhedral very fine-grained monazites associated with Celestine; (f) Elongated euhedral very fine grained two monazite grains associated with celestine. 
Table 2. Representative chemical composition of monaztite from the Mushgai khudag complex.

\begin{tabular}{|c|c|c|c|c|c|c|c|}
\hline \multirow{3}{*}{$\begin{array}{c}\text { Sample from } \\
\text { Analysis } \\
\text { location }\end{array}$} & \multicolumn{4}{|c|}{ Monazite zone } & \multicolumn{2}{|c|}{ Carbonatite zone } & \multirow{3}{*}{$\begin{array}{c}\text { Apatite zone } \\
\text { MH117 }\end{array}$} \\
\hline & MH5 & MH204 & MH24 & MH25 & MH93 & MH96 & \\
\hline & Grain & Rim & Rim & Rim & Grain & Grain & \\
\hline $\mathrm{Na}_{2} \mathrm{O}$ & - & 0.27 & - & - & - & - & - \\
\hline $\mathrm{CaO}$ & 5.25 & 11.94 & 8.09 & 8.26 & 0.54 & 0.52 & 0.52 \\
\hline $\mathrm{SrO}$ & 0 & 2.51 & 2.68 & 2.26 & 0 & 0 & 0 \\
\hline $\mathrm{Nd}_{2} \mathrm{O}_{3}$ & 5.55 & 6.57 & 7.54 & 7.05 & 6.08 & 7.37 & 9.16 \\
\hline $\mathrm{Ce}_{2} \mathrm{O}_{3}$ & 31.97 & 22.78 & 25.32 & 25.42 & 34.89 & 35.97 & 33.97 \\
\hline $\mathrm{Pr}_{2} \mathrm{O}_{3}$ & 1.86 & 2.21 & 2.56 & 2.67 & 2.11 & 3.08 & 2.45 \\
\hline $\mathrm{La}_{2} \mathrm{O}_{3}$ & 21.31 & 17.77 & 20.5 & 20.45 & 25.6 & 24.05 & 22.7 \\
\hline $\mathrm{SiO}_{2}$ & 0 & 0 & 0 & 0 & 0.64 & 1.01 & 0 \\
\hline $\mathrm{SO}_{3}$ & 0.93 & 4.06 & 3.16 & 2.9 & 0.56 & 1.26 & 1.5 \\
\hline $\mathrm{P}_{2} \mathrm{O}_{5}$ & 24.97 & 26.64 & 27.77 & 27.98 & 30.25 & 27.15 & 28.99 \\
\hline $\mathrm{FeO}$ & 1.53 & 0.47 & 0 & 0 & 0.85 & 0 & 0 \\
\hline Total & 93.37 & 95.22 & 97.62 & 96.99 & 101.52 & 100.41 & 103 \\
\hline $\mathrm{LREE}_{2} \mathrm{O}_{3}$ & 60.69 & 49.33 & 55.92 & 55.59 & 68.68 & 70.47 & 68.28 \\
\hline $\mathrm{Na}$ & 0.00 & 0.02 & 0.00 & 0.00 & 0 & 0.00 & 0.00 \\
\hline $\mathrm{Ca}$ & 0.23 & 0.47 & 0.32 & 0.33 & 0.02 & 0.02 & 0.02 \\
\hline $\mathrm{Sr}$ & 0.00 & 0.05 & 0.06 & 0.05 & 0 & 0.00 & 0.00 \\
\hline $\mathrm{Nd}$ & 0.08 & 0.09 & 0.10 & 0.09 & 0.08 & 0.10 & 0.12 \\
\hline $\mathrm{Ce}$ & 0.49 & 0.31 & 0.35 & 0.35 & 0.48 & 0.52 & 0.47 \\
\hline Pr & 0.03 & 0.03 & 0.03 & 0.04 & 0.03 & 0.04 & 0.03 \\
\hline $\mathrm{La}$ & 0.33 & 0.24 & 0.28 & 0.28 & 0.36 & 0.35 & 0.32 \\
\hline $\mathrm{Si}$ & 0.00 & 0.00 & 0.00 & 0.00 & 0.02 & 0.04 & 0.00 \\
\hline $\mathrm{S}$ & 0.03 & 0.11 & 0.09 & 0.08 & 0.02 & 0.04 & 0.04 \\
\hline $\mathrm{P}$ & 0.87 & 0.83 & 0.88 & 0.89 & 0.96 & 0.91 & 0.93 \\
\hline $\mathrm{Fe}$ & 0.05 & 0.01 & 0.00 & 0.00 & 0.03 & 0.00 & 0.00 \\
\hline LREE & 0.92 & 0.67 & 0.76 & 0.76 & 0.95 & 1.02 & 0.95 \\
\hline
\end{tabular}

Note: Cations in crystal-chemical formulae normalized to 4 oxygen atoms.

\section{Discussion}

The mobility of the rare earth elements in hydrothermal fluid is strongly depend on the relative concentrations of possible ligands, such as $\mathrm{F}^{-}, \mathrm{Cl}^{-}, \mathrm{OH}^{-}, \mathrm{SO}_{4}^{2-}$, and $\mathrm{CO}_{3}^{2-}$, and the $\mathrm{pH}$ of the solution. Also, hydrothermal fluid's temperature and pressure are important [17].

It has been reported that $\left(\sum \mathrm{REE}=200 \mathrm{ppb}\right)$ concentrations, in acid waters at Yellowstone hydrothermal system (USA) [18]. REE content tends to be increased in Low-pH waters than neutral or alkaline solutions. Low-pH, sulfate-rich fluids with the highest REE concentrations in hydrothermal fluids have been found at the Valles-caldera ( $\sum$ REE $\left.=339 \mathrm{ppb}\right)$, [19].

Moreover, Saline magmatic solutions with high-temperature can effective carry REE. Also, the solutions can transport a large amount of REE (1290 ppm) in the ancient hydrothermal system [20]. Wood's (1990) experimental data and theoretical predictions suggest that the sulfate ions form relatively strong complexes with REE. At the temperatures $\geq 200^{\circ} \mathrm{C}$ and in the absence of other ligands, sulfate complexes will be the dominant form of REE transport, even at free sulfate environment [21]. 
Nevertheless, Brookins (1989) noted that the REE with sulfate complexes is considerably important only in the absence of other potentially strong ligands. If strong complex-forming ligands such as fluoride, carbonate, or possibly the phosphate were present, the suggested sulfate complexes with REE would probably not be important because of the strong affinity of the hard REE ions for hard ligands such as $\mathrm{F}^{-}, \mathrm{OH}^{-}$, and $\mathrm{PO}_{4}^{3-}$, especially at higher temperatures [22]. It has been suggested that the REE cations are classified as hard ions, as ions with a small size and high charge. Hard cations bind preferentially with hard ligands [23].
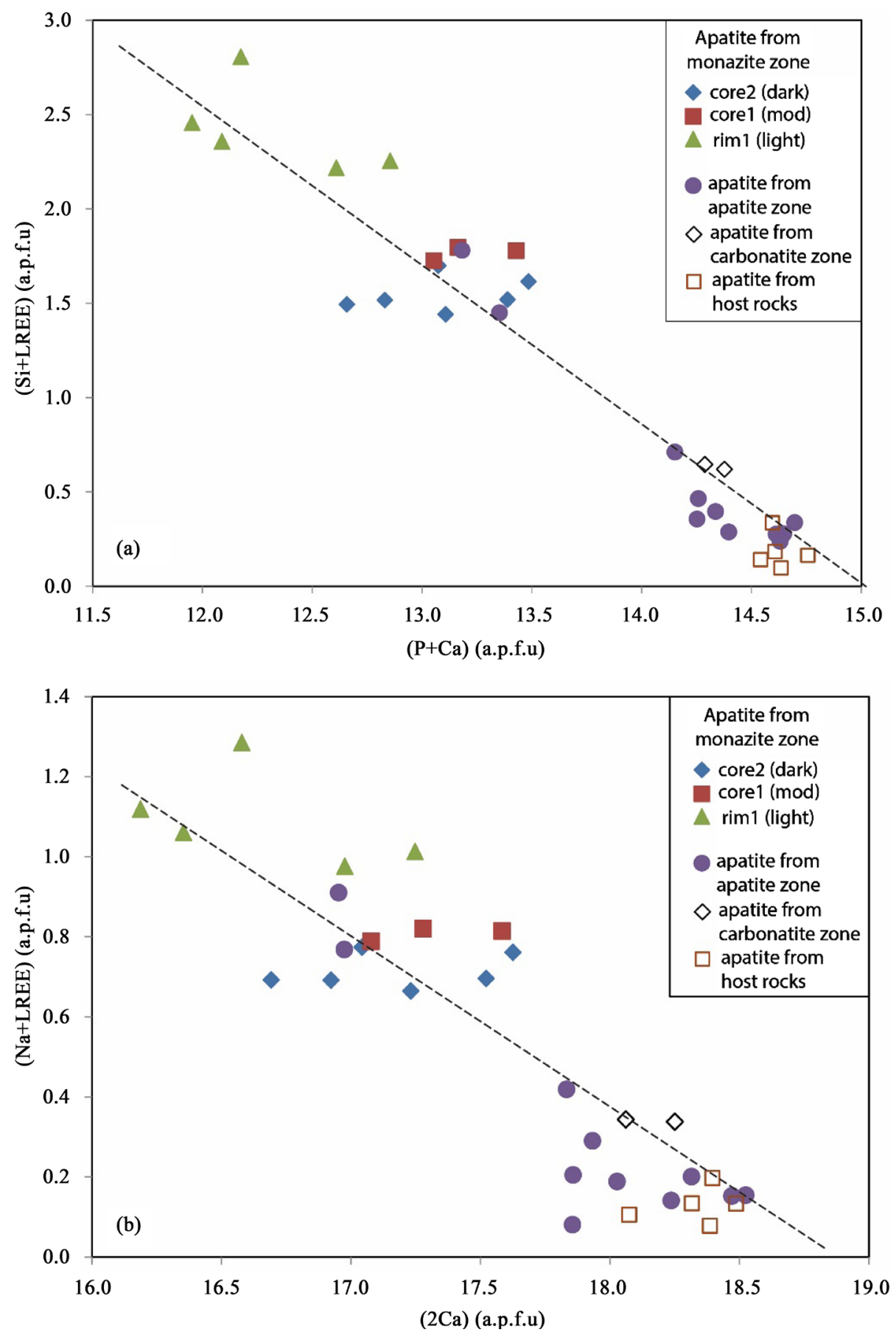

Figure 4. Plots of cation values as atoms per formula unit (a.p.f.u) reflecting coupled substitution reaction (a) $\mathrm{Si}^{4+}+\mathrm{LREE}^{3+}$ $=\mathrm{P}^{5+}+\mathrm{Ca}^{2+}$, (b) $\mathrm{Na}^{+}+\mathrm{LREE}^{3+}=2 \mathrm{Ca}^{2+}$, for the apatite from monazite zone, that discern to core2 (dark), core1 (moderate), rim1 (light) areas. Apatite from carbonatite zone, apatite zone, and in syenite (after Harlov et al., 2003). 

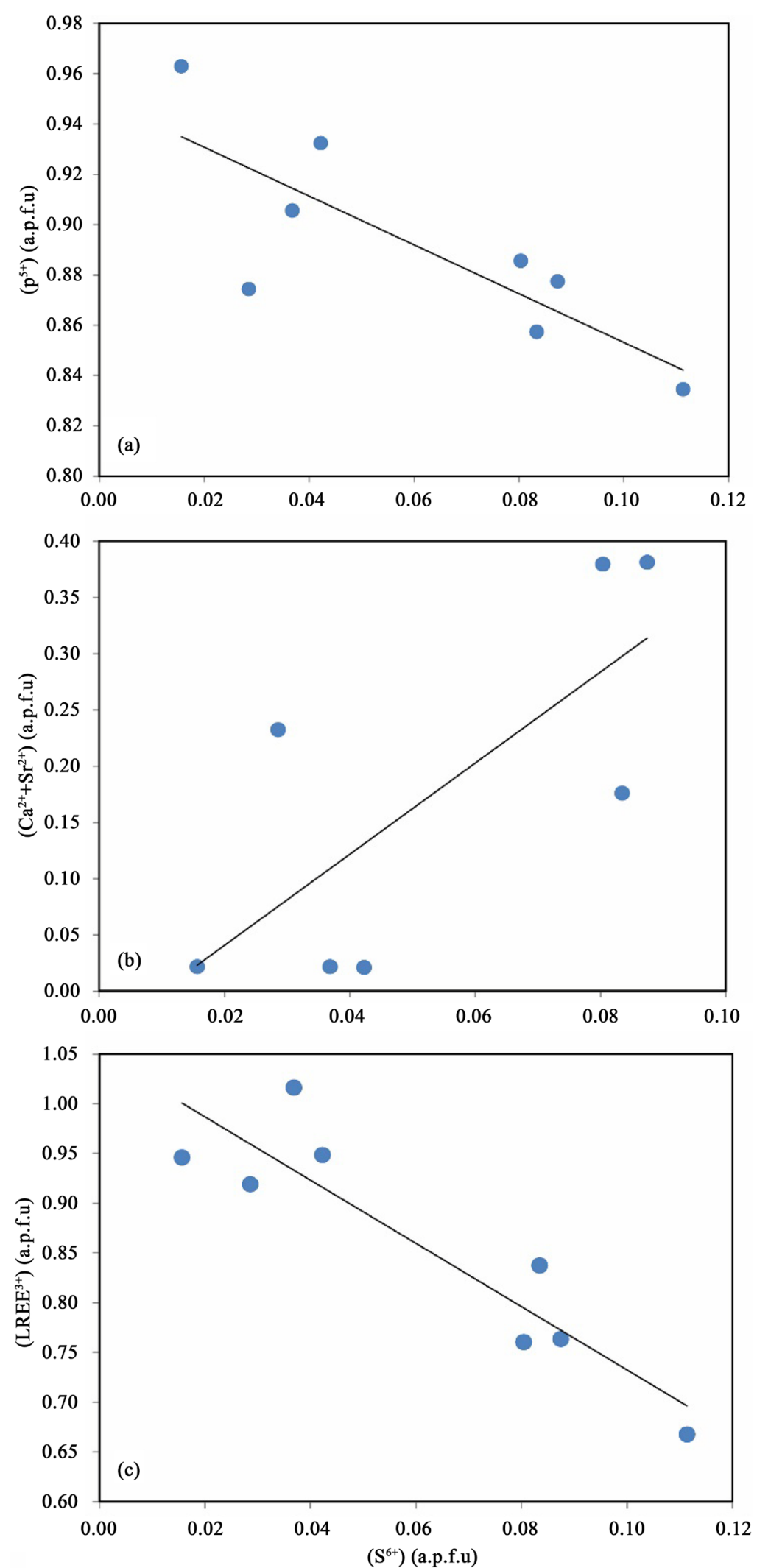

Figure 5. Variation in minor components "in Ca-Sr-rich monazite from the Mushgai khudag deposit” (a) $\mathrm{P}^{5+}$ versus $\mathrm{S}^{6+}$, (b) $\left(\mathrm{Ca}^{2+}+\mathrm{Sr}^{2+}\right)$ versus $\mathrm{S}^{6+}$, and (c) $\mathrm{LREE}^{3+}$ versus $\mathrm{S}^{6+}$ (after Chakhmourdain and Mitchell, 1999). 
In this study, we suggest sulfate ligand, which encouraged the rare earth elements mobility, based on the chemical characteristics of monazite-bearing apatite in the Mushgai khudag complex. It is no doubt that the hard ligand phosphate is abundant with a high alkaline condition of the first stage of magmatism in the Mushgai khudag complex. However, the hard ligands fluoride and carbonate were dominant with the carbonatite magmatism. In case, the sulfate ligand complexed with REE in the Mushgai khudag complex, it could be the other ligands abundance would have been minor. In addition, the $\mathrm{pH}$ condition should be low. Thus, the sulfate ligand complexing with REE may have been related to the last stage of hydrothermal activity (metasomatism) in the Mushgai khudag complex. Our result show that the monazite in the Mushgai khudag complex. Our result show that the monazite contains $\mathrm{CaSO} 4$ (anhydrite), $\mathrm{SrSO}_{4}$ (celestine) component. In other words, the monazite was formed by sulfate-rich fluid induced metasomatism. The $S^{6+}$ versus $L_{R E E}{ }^{3+}$ diagram show the $S^{6+}$ moderate positive correlation with $\mathrm{LREE}^{3+}$. The $\mathrm{S}^{6+}$ content is increased with $\mathrm{LREE}^{3+}$ increase in the apatite from the Mushgai khudag complex. Especially the sulfur-rich monazite forming (core2), (core1), (rim1) areas are strongly enriched in S content suggesting that the sulfur-rich monazite in the Mushgai khudag complex strongly depends on the sulfate ligand (Figure 6).

\section{Conclusion}

In the Mushgai khudag deposit, LREE-bearing minerals are dominantly fluorapatite, hydroxyl-bearing fluorapatite, and monazite. Fluorapatite and hydroxyl-bearing fluorapatite can be found in all mineralization zones, whereas monazite distributed limited area. S and Sr-rich individual monazite grains have been found in the rim of fluorapatite and hydroxyl-bearing fluorapatite in the samples from the Monazite zone. It can be explained that the Mushgai khudag rocks were affected by strong REE mineralization due to various stages of magmatic and hydrothermal segregations. REEs have a strong mobility in the last stage of metasomatism due to sulfate-rich fluid complexed with REE. Apatite from monazite zone shows diverse zoning texture, and individual high S content monazite grains are formed along the rim of apatite crystals, and is well described in the present study.

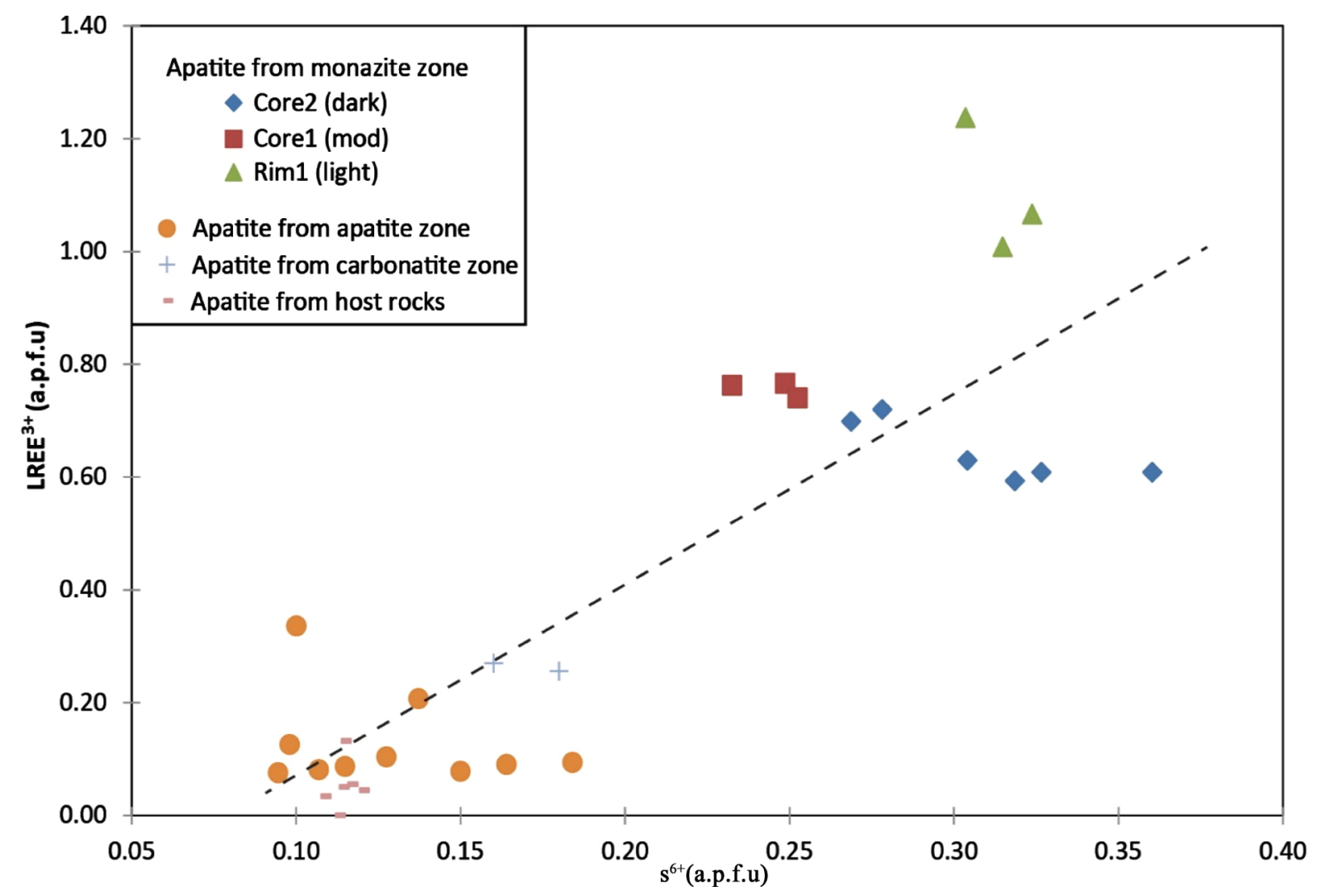

Figure 6. Plots of cation values as atoms per formula unit (a.p.f.u), $S^{6+}$ versus LREE $^{3+}$ for the apatite from monazite zone, discern to core2 (dark), core1 (moderate), rim1 (light) areas. Apatite from carbonatite zone, apatite zone, and in syenite. 
Such zonation of apatite with monazite is a relatively rare case in terms of REE mineralization with phosphate.

\section{Acknowledgements}

This work was supported by the Korea Institute of Energy Technology Evaluation and Planning (KETEP) grant funded by the Korea government Ministry of Knowledge Economy (20152510101890) and the National Research Foundation of Korea (NRF) grant funded by the Korea government (MSIP), (2014R1AEAEA01007294). An earlier manuscript of this paper was improved by R. Giere and a number of referees who suggested valuable recommendations. First stage of the manuscript improvement was made by Professor B. Munkhtsengel and Mr, D. Batbold. We wish to thank Professor O. Gerel for last critical reading of the English content and greatly improved this paper. Finally, thanks to the fellows of the "Mongol Gazar" company for their help to provide research opportunity, especially Mrs, M. Delgertsetseg for her help in field work.

\section{References}

[1] Dorjpalma, E. (2014) Mineralogical and Geochemical Study of the Mushgai Khudag Deposit. Master Dissertation, Department of Earth and Environmental Science, Korea University, Seoul.

[2] Baatar, M., Ochir, G., Kynicky, J., Iizumi, S. and Comi-Ciaramonti, P. (2013) Some Notes on the Lugiin Gol, Mushgai-Khudag- and Bayan-Khoshuu Alkaline Complexes, Southern Mongolia. International Journal of Geosciences, 4, $1200-1214$.

[3] Harlov, D.E. and Forster, H.J. (2003) Fluid-Induced Nucleation of (Y+REE)-Phosphate Mineral within Apatite: Nature Experiment. Part II. Fluorapatite. American Mineralogist, 88, 1209-1229. http://dx.doi.org/10.2138/am-2003-8-905

[4] Harlov, D.E., Forster, H.J. and Schmidt, C. (2003) High P-T Experimental Metasomatism of a Fluorapatite with Significant Britholite and Fluorsellestadite Components: Implications for LREE Mobility during Granulite-Facies Metamorphism. Mineralogical Magazine, 67, 61-72. http://dx.doi.org/10.1180/0026461036710084

[5] Samoilov, V.C., Ivanov, V.G., Senge, D. and Kovalenko, V.I. (1983-1984) Prognostic Evaluation of Mushgia Rare Earth's Deposit. Report.

[6] Pan, Y. (1997) Zircon and Monazite Forming Metamorphic Reactions at Manitawadge Ontaria. Canada, Mineral, 35, 105-119.

[7] Harlov, D.E., Forster, H.J. and Nijland, T.G. (2002) Fluid-Induced Nucleation of (Y + REE) Phosphate Minerals in Apatite: Nature and Experiment. Part I. Chlorapatite. American Mineralogist, 87, 245-261. http://dx.doi.org/10.2138/am-2002-2-306

[8] Pan, Y. and Fleet, M.E. (2002) Compositions of the Apatite-Group Minerals: Subtitution Mechanisms and Controlling Factors. Reviews in Mineralogy and Geochemistry, 48, 13-49. http://dx.doi.org/10.2138/rmg.2002.48.2

[9] Chakhmouradian, A.R. and Mitchell, R.H. (1999) Niobianilmenite, Hydroxylapatite and Sulfur-Rich Monazite: Alternative Hosts for Incompatible Elements in Calcite Kimberlite from Internatsional'Naya, Yakutia. The Canadian Mineralogist, 37, 1177-1189.

[10] Bayarsaikhan, T. and Bayardalai, S. (2010) Exploration Report of the Mushgai Khudag Deposit. Report. (In Mongolia)

[11] Watt, G.R. (1995) High-Thorium Monazite-(Ce) Formed during Disequilbrium Melting of Metapelties under Granulite-Facies Conditions. Mineralogical Magazine, 59, 735-743. http://dx.doi.org/10.1180/minmag.1995.059.397.14

[12] Pan, Y. and Fleet, M.E. (1995) Site Preference of Rare Earth Elements in Fluorapatite. American Mineralogist, 80, 329-335.

[13] Pan, Y. and Fleet, M.E. (1993) Oriented Monazite Inclusions in Apatite Porphyroblasts from the Hemlo Gol Deposit, Ontaria. Canada, Mineral, Mag, 57, 697-707.

[14] Chakhmouradian, A.R. and Mitchel, R.H. (1998) Lueshite, Pyrochlore and Monazite-(Ce) from Apatite-Dolomite Carbonatite, Lesnaya Varaka Complex, Kola Peninsula, Russia. The Canadian Mineralogist, 62, 769-782.

[15] Rose, D. (1980) Barbanatite, CaTh $\left(\mathrm{PO}_{4}\right)_{2}$, a New Mineral of the Monazite Group. Neues Jahrbuch für MineralogieMonatshefte, 247-257.

[16] Jaroslav, P., Martin, O., Peter, B. and Bartosz, B. (2010) Methamorphic-Hydrothermal REE Minerals in the Bacuch Magnetite Deposit, Western Carpathias, Slovakia: (Sr, S)-Rich Monazite-(Ce) and Nd-Dominant Hingganite. The Canadian Mineralogist, 48, 81-94. http://dx.doi.org/10.3749/canmin.48.1.81

[17] Giere, R. (1993) Transport and Deposition of REE in $\mathrm{H}_{2} \mathrm{~S}-$ Rich Fluids: Evidence from Accessory Mineral Assemblages. Chemical Geology, 110, 251-268. http://dx.doi.org/10.1016/0009-2541(93)90257-J

[18] Palmer, M.A. (1998) Rare Earth Element Speciation in Geothermal Fluids from Yellowstone National Park, Wyoming, 
USA. Geochimica et Cosmochimica Acta, 62, 657-663. http://dx.doi.org/10.1016/S0016-7037(97)00367-0

[19] Michard, A. (1989) Rare Earth Element Systematics in Hydrothermal Fluids. Geochimica et Cosmochimica Acta, 53, 745-750. http://dx.doi.org/10.1016/0016-7037(89)90017-3

[20] Banks, D.Y. (1994) REE Composition of an Aqueous Magmatic Fluid: A Fluid Inclusion Study from the Captain Pluton, New Mexico. Chemical Geology, 113, 22. http://dx.doi.org/10.1016/0009-2541(94)90070-1

[21] Wood, A. (1990) The Aquesous Geochemistry of the Rare-Earth Elements and Yttrium. Theoretical Predictions of Speciation in Hydrothermal Solutions to $350^{\circ} \mathrm{C}$ at Saturation Water Vapor Pressure. Chemical Geology, 88, 99-125. http://dx.doi.org/10.1016/0009-2541(90)90106-H

[22] Brookins, D. (1989) Aqueous Geochemistry of Rare Earth Elements, in Geochemistry and Mineralogy of the Rare Earth Elements. Reviews in Mineralogy, 21, 201-225.

[23] Ahrland, S. (1968) Thermodynamics of Complex Formation between Hard and Soft Acceptors and Donors. Structure and Bonding, 5, 118-149. http://dx.doi.org/10.1007/BFb0118849 